\title{
Thinking, Deciding, Acting: Gaps and Relations
}

\author{
AISTÉ DIRŽYTE் \\ Department of Philosophy and Cultural Studies, Faculty of Creative Industries, Vilnius Gediminas Technical University, 1 Trakų St., \\ 01132 Vilnius \\ Email: aiste.dirzyte@vgtu.lt
}

\begin{abstract}
In the first part of this essay the author points to possible gaps and relations between cognitive (thinking, reasoning, decision making) and behavioural (acting) processes. Mainstream cognitive sciences assume that thinking might result in decision making which might result in acting: i.e. cognitive processes are related to behavioural processes. Perceptual distortion, inaccurate judgment, illogical interpretation, or what is broadly called irrationality might lead to destructive behaviours on personal or societal levels. It is noted that some researchers focus on mediating/moderating factors and correlations between thinking, decision making and acting, while others focus on gaps. In the second part the author reviews the articles presented in this issue and questions as they have been discussed by others: heuristics as a method that uses principles of effort-reduction and simplification, hermeneutics of values based on Max Weber concepts, Bakhtin's ideas on philosophy of the act and diachronic, dialogistic linguistic activities, phenomenology of solidarity implying that the acts determine experience of the world in modi 'we', Heidegger's thinking, assuming the vital link between practical and ontological aspects of Heideggerian phenomenology, the evidence on theory and practice of new media and the development of concepts of creativity.
\end{abstract}

Keywords: cognitive processes, behaviour, relations

Mainstream cognitive sciences assume that thinking might result in decision making which might result in acting. In other words, cognitive processes are related to behavioural processes. Some researchers focus on mediating/moderating factors and correlations between the three (e.g. Field, Beeson, Jones 2015), while others focus on gaps (Kahneman, Tversky 1996; Hilbert 2012).

As noted by authors (Baron 2007), individuals create their own 'subjective social reality' from their perception of the input which may dictate their behaviour in the social world. Perceptual distortion, inaccurate judgment, illogical interpretation, or what is broadly called irrationality might lead to destructive behaviours on personal or societal levels.

Tversky and Kahneman explained human differences in decision making in terms of heuristics and demonstrated several replicable ways in which human decisions differ from rational choice theory. They described heuristics as simple for the brain to compute but sometimes introducing 'severe and systematic errors' (Tversky, Kahneman 1974: 1125) such as activating stereotypes and inaccurate judgements of others (Haselton 2005: 726). Alternatively, Gerd Gigerenzer 
argued that heuristics should consider rationality as an adaptive instrument that is not identical to the rules of formal logic or the probability calculus (Gigerenzer 1996: 592-596).

Heuristics involves mental shortcuts which provide swift estimates about the possibility of uncertain occurrences (Baumeister, Bushman 2010: 141). Sometimes this could be presumably adaptive and lead to more effective actions in a given context or enable faster decisions when timeliness is more valuable than accuracy. However, sometimes it could notify about information processing limitations, resulting from a lack of appropriate mental mechanisms (bounded rationality) (Morewedge, Kahneman 2010: 435-440).

This issue analyses the questions related with the topic of thinking, deciding and acting: their gaps and relations. In the article Two Types of Heuristics in Moral Decision Making, the authors discuss heuristics as a method that uses principles of effort-reduction and simplification, which allow decision makers to process information in a less effortful manner than one would expect from an optimal decision rule (Shah, Oppenheimer 2008: 207). The authors argue that moral assessment is made on the basis of information about attributes of the act, such as its compliance with the norm, consequences, opinions of others about it, etc., and these attributes may be morally relevant (those attributes that an individual could, in the case of rational analysis, recognize as a direct basis for moral assessment) and morally irrelevant (those which would not be recognized in such a status). Authors indicate that heuristics of the first type implies a simplified assessing of the target attribute based on partial information about morally relevant attributes of an act, while heuristics of the second type operates through a process of attribute substitution when irrelevant attributes are used to assess the target attribute. Authors conclude that considerations outlined in the article help to clarify the understanding of moral heuristics and the mechanisms that underlie them.

Heuristics concerns decision making, whereas hermeneutics concerns the interpretation of texts which is cognitive activity as well. Hermeneutics emerged as a system suitable not only for religion or humanism, but also for social sciences, facilitated by the expansion of the meaning of textuality itself: what was conventionally understood as something that refers only to things that are or can be written has been stretched to cover almost anything that has something to do with human life. The article on Axiological Interpretation in the Thought of Max Weber defends the thesis that the axiological interpretation (Wertinterpretation) of Max Weber might play an important role in the field of social sciences methodology and also within philosophical hermeneutics. The author suggests for establishing a hermeneutics of values starting from general hermeneutics, which has considerably improved since Schleiermacher.

Behaviour, or acting, is a process related to thinking. The well-known Toward a Philosophy of the Act reveals Bakhtin's claims regarding the acknowledgment of the uniqueness of one's participation in Being: 'I both actively and passively participate in Being,' 'My uniqueness is given but it simultaneously exists only to the degree to which I actualize this uniqueness', 'Because I am actual and irreplaceable I must actualize my uniqueness' (Bakhtin 1993: 41). From the point of some cognitive authors (e.g. Field et al. 2015), constructive cognitive processes might lead to constructive behavioural outcomes. The article on Comparative Analysis of Bakhtin's and Saussure's Approaches in the Context of Structuralism and Poststructuralism investigates Bakhtin's ideas on diachronic, dialogistic linguistic activities. Authors indicate that being positive about the works of the founder of structural linguistics Saussure and simultaneously taking a critical approach to the Saussure's idea of arbitrary nature of an utterance, Bakhtin advocates the systemic nature of an utterance and considers that each sentence is formed by us as an element of the system, taking into account the whole and in harmony with it. Authors conclude that representatives of poststructuralism, 
which replaced structuralism, highly appreciate the ideas of Bakhtin, recognize priority ranking and advantages of a number of ideas of his theory over similar concepts of the Western world.

The article on An Outline of a Phenomenology of Solidarity: Beyond the Bridge Problem presents main elements, problems and preliminary solutions connected to a phenomenology of solidarity. The author defines the bridge problem as an attempt to bind subjective and intersubjective levels of constitution, presents the act of solidarization as a complex act which binds cognitive, volitional and affective dimensions, sketches an alternative approach to a phenomenology of solidarity that leads beyond the bridge problem, namely, Husserl's theory of constitution of groups in joint action. The author indicates that the main aim of this article was an attempt to analyse solidarity phenomenologically as a social phenomenon and show that acts of solidarization constitute groups, and that the acts determine experience of the world in modi 'we'.

The article The Everyday in Heidegger's Revolutionary Thought emphasizes the primacy of the everyday in Heidegger's thinking, assuming the vital link between practical and ontological aspects of Heideggerian phenomenology. The author recommends dealing not solely with the phenomenological, but also with the hermeneutical aspects of Heidegger's philosophy.

In the article The Formation of the Concept of Television Media: The Phenomenon of Direct Broadcast, the author describes that television in Lithuania has been established more than 90 years ago. The author indicates that the emergence of the new media revealed the old-new contraposition, and the analysis of the processes of the growth of new media has not only a historical value, but also provides with an opportunity to take a fresh look at today's media, and to procrastinate its development. Based on the information found in the Paris Saint-Genevieve Library Funds (1930s-1960s), this article analyses the evidence on theory and practice of the Western TV.

In the article Creativity Concepts Shift: From Mysticism to Modern Approach, the authors analyse development of the concepts of creativity. They remind that the concepts of creativity developed historically. The analysis begins with Plato's discussion on poetry as initiating from divine inspiration. The authors reflect upon creativity concepts in Renaissance, Rationalism, Romanticism, 20th and 21st centuries.

To sum up, this issue presents some valuable information to contemplate on possible gaps and relations between thinking, deciding and acting.

Received 24 June 2018 Accepted 1 August 2018

\section{References}

1. Bakhtin, M. M. 1993. Toward a Philosophy of the Act, eds. V. Liapunov and M. Holquist. Transl. by V. Liapunov. Austin: University of Texas Press.

2. Baron, J. 2007. Thinking and Deciding. 4th ed. New York: Cambridge University Press.

3. Baumeister, R. F.; Bushman, B. J. 2010. Social Psychology and Human Nature. International Edition. Belmont: Wadsworth.

4. Field, T. A.; Beeson, E. T.; Jones, L. K. 2015. “The New ABCs: A Practitioner's Guide to Neuroscienceinformed Cognitive-behavior Therapy", Journal of Mental Health Counseling 37(3): 206-220. DOI: 10.17744/1040-2861-37.3.206.

5. Gigerenzer, G. 1996. "On Narrow Norms and Vague Heuristics: A Reply to Kahneman and Tversky (1996)", Psychological Review 103(3): 592-596.

6. Gigerenzer, G.; Goldstein, D. G. 1996. "Reasoning the Fast and Frugal Way: Models of Bounded Rationality", Psychological Review 103(4): 650-669. DOI: 10.1037/0033-295X.103.4.650.

7. Hilbert, M. 2012. "Toward a Synthesis of Cognitive Biases: How Noisy Information Processing Can Bias Human Decision Making", Psychological Bulletin 138(2): 211-237.

8. Kahneman, D.; Tversky, A. 1996. "On the Reality of Cognitive Illusions", Psychological Review 103(3): 582-591. DOI: 10.1037/0033-295X.103.3.582. 
9. Kahneman, D.; Tversky, A. 1972. “Subjective Probability: A Judgment of Representativeness", Cognitive Psychology 3(3): 430-454. DOI: 10.1016/0010-0285(72)90016-3.

10. Morewedge, C. K.; Kahneman, D. 2010. "Associative Processes in Intuitive Judgment", Trends in Cognitive Sciences 14(10): 435-440. DOI: 10.1016/j.tics.2010.07.004.

11. Shah, A. K.; Oppenheimer, D. M. 2008. "Heuristics Made Easy: An Effort-reduction Framework", Psychological Bulletin 134(2): 207-222.

12. Tversky, A.; Kahneman, D. 1974. "Judgement under Uncertainty: Heuristics and Biases", Science 185(4157): 1124-1131. DOI:10.1126/science.185.4157.1124.

\title{
AISTÉ DIRŽYTE்
}

\section{Mąstyti, nuspręsti, veikti: neatitikmenys ir sąsajos}

\author{
Santrauka
}

Pirmoje straipsnio dalyje aptariami kognityvinių (mąstymo, samprotavimo, sprendimų prièmimo) ir elgesio (veikimo, atlikimo) procesų neatitikimai bei sąsajos. Nurodoma, kad kognityviniuose moksluose mąstymo rezultatas gali būti sprendimo priemimas, o sprendimo priemimo rezultatas - konkretus elgesys (veiksmas), kitaip tariant, kognityviniai procesai yra susiję su elgsenos procesais. Suvokimo iškraipymai, neteisingas samprotavimas, neloginès interpretacijos (iracionalumas) asmenims ir visuomenei gali sukelti destruktyvias pasekmes. Atkreipiamas demesys, kad šiuolaikiniuose kognityviniuose moksluose kai kurie autoriai nagrinėja mąstymo, sprendimų priemimo bei veikimo (elgsenos) koreliacijas arba jų tarpusavio ryšius moderuojančius / medijuojančius veiksnius, o kiti autoriai gilinasi ị neatitikimą tarp mąstymo, sprendimų priemimo ir veiksmo (elgesio) procesų.

Antroje dalyje apžvelgiami šiame žurnalo numeryje publikuojami straipsniai, kitų autorių svarstomos temos, iškelti klausimai: dviejų tipų euristika, vertybėmis grịsta hermeneutika, Michailo Bachtino veiksmo ir lingvistinès veiklos filosofija, solidarumo ir Martino Heideggerio fenomenologija, naujosios medijos teorija ir praktika, kūrybiškumo sampratos istorinè raida.

Raktažodžiai: kognityviniai procesai, elgesys, ryšiai 